logos_i_ethos_2020_special issue, pp. 51-72

DOI: http://dx.doi.org/10.15633/lie.3767

Teresa Obolevitch

https://orcid.org/0000-0002-6834-6142

\title{
George Florovsky's critique of the Russian religious-philosophical renaissance: an attempt at evaluation
}

George Florovsky (1893-1979) belongs to a circle of people who exerted considerable, or even decisive influence on the shape of the Russian intellectual culture in the 2oth century. This prominent philosopher, theologian, active

Sr Teresa Obolevitch - Ph. D., Professor, a chair of philosophy with a habilitation degree, a chair of Russian and Byznatine Philosophy at the Faculty of Philosophy, UPJPII in Cracow, a member of the Copernicus Center for Interdisciplinary Studies. participant in the ecumenical movement, author of many works devoted to Russian and Patristic thought, and an educator of several generations of outstanding intellectuals (both Russian émigrés and Western researchers) is above all known as a reviver of the Patristic tradition ${ }^{1}$ (or the initiator of the so-called Neopatristic synthesis) in the past century. Not only did he influence the shape of the Russian philosophical and theological culture, but he also contributed (along with many Catholic and Protestant theologians) to the "Patristic turn" in the last century. The present text primarily focuses on Florovsky's perception of the Russian thought heritage and the phenomenon of the so-called religiousphilosophical renaissance, which came to be manifested not so much through the revival (which is suggested by the term "renaissance"), but through the nascence of original Russian philosophical thought (first in Russia as such, and following the October Revolution - mainly in exile).

1 See R.J. Sauvé, Florovsky’s Tradition, "Greek Orthodox Theological Review” 55 (2010) no. 1-4, p. 213. 
This problematic is addressed in a book by Paul Gavrilyuk, ${ }^{2}$ an American scholar of Ukrainian origin, as well as in some chapters of my publication on the work of Fr. George Florovsky and Vladimir Lossky. ${ }^{3}$ However, there appear more and more materials that shed new light on the issues concerned with Florovsky's attitude to the Russian philosophical and religious tradition, as well as the role he played in the process of the development of the Neopatristic movement. Besides, it is worthwhile juxtaposing Florovsky's thought with that of Vasily Zenkovsky, another émigré author who shared his critical attitude towards the Russian style of philosophising, though he did not deny the very idea of religious philosophy.

\section{Evaluation of the religious-philosophical situation}

Florovsky presents his attitude to the Russian religious-philosophical renaissance in essays treating of the work of its "father" - Vladimir Solovyov (1853-1900) and other Russian thinkers of the Silver Age, such as Pavel Florensky (1882-1937) and Sergius Bulgakov (1871-1944). The controversy over sophiology which arose in the 1930s, and in which Florovsky's opinion played a substantial role, presented him with a great opportunity to express his thoughts on the subject. It is worth noting his fundamental work Ways of Russian Theology (1937) as well as the recently published archival text Russian Philosophy in Emigration (completed in 1930, which means that it was written more or less at the same time as the above-mentioned book, but it contains a somewhat different and less harsh judgement of the development of the Russian thought contemporary with Florovsky's lifetime).

Let us begin with a symptomatic assessment of the condition of the Russian intellectual culture of the Silver Age, as presented by Florovsky in Ways of Russian Theology. The author writes thus:

2 P.L. Gavrilyuk, Georges Florovsky and the Russian Religious Renaissance, Oxford 2013.

3 T. Obolevitch, Filozofia rosyjskiego renesansu patrystycznego: o. Gieorgij Fłorowski, Włodzimierz Łosski i inni, Kraków 2014. 
Religious philosophy became a special type of philosophical confession and construction, marking the return of metaphysics to its religious roots. (...) The philosophers of those years became religious in their psychological make-up. (...) Other philosophical influences, such as Husserl's phenomenology and the resurgence of the great idealist systems, also took on a religious cast in Russia. ${ }^{4}$

Florovsky also emphasises that the religious-philosophical revival at the end of the 19th century and in the first decades of the 2oth century was quite often of gnostic character, thus departing from Christian teachings. In consequence philosophy took the place of theology. It was only Florensky and Bulgakov that came close to theological issues, but they too crossed the boundaries of orthodoxy by propagating the doctrine of Sophia - Divine Wisdom that mediates between God and the created world. The author of Ways of Russian Theology owed a lot to both the thinkers (in particular, thanks to an invitation from Fr. Sergius Bulgakov he became a patrology lecturer at St. Serge Institute in Paris), but it was Florovsky who became one of the experts tasked with providing an official evaluation of sophiology (at the behest of Metropolitan Eulogius). In 1936 he signed a document - the so-called special opinion (особое мнение), drawn up by Fr. Sergius Chetverikov, which stated that the doctrine of Sophia contained dangerous and even heretical views at variance with the Holy Scriptures and the tradition of the Church Fathers.

What is more, in Florovsky's estimation, both the Russian philosophy and theology, which had been developed under the influence of other traditions (first the Latin-Catholic one - at the Kyiv-Mohyla Academy established in the 17th century - and then - during the reign of Peter I the German-Protestant one), squandered the Patristic heritage proper to the Byzantine-Slavic culture.

Theological scholarship was brought to Russia from the West. Having been a stranger to Russia for too long, it stubbornly spoke in its own peculiar and foreign

4 G. Florovsky, Ways of Russian Theology, vol. 2, trans. by R. L. Nichols, Vaduz 1987, pp. 267-268. 
tongue - instead of in the language of daily life or the language of prayer - and remained a foreign element in the church organism. (...) Theological searching could find no fertile soil for itself. (...) [I]n theology the patristic style and method was lost. The works of the fathers became dead historical documents. ${ }^{5}$

In the Silver Age culture, characterised by the emergence of great philosophical systems authored by Vladimir Solovyov and other thinkers, "a return from Jerusalem to Athens is out of date and useless." But a reverse process should be taking place: not restoration of the Greek manner of philosophising (even in the spirit of idealism), but Christianisation of philosophical thought, suffusing it with the content of the Revelation, which was the case of the Patristic Period. "What was needed was a spiritual «philosophy of heart» - exhorted Florovsky - even if it "does not replace dogmatic theology, it at least obscures it." noteworthy that in Russia the "philosophy of heart" has a long tradition; it was, inter alias, pursued by Pamfil Yurkevich (around 1826/27-1874), who supervised the M.A. thesis written by Vladimir Solovyov, the "father" of the Russian thought, as well as Pavel Florensky. In general, the 19th and 2oth centuries saw continuation of the process of "occidentalisation" of both theology and philosophy, which gave rise to the development of impressive religious-philosophical systems, but at the same time brought about cutting off of the roots of the Russian Orthodox faith. Florovsky writes as follows:

The Orthodox theologian up to now has been too dependent on western support for his personal efforts. His primary sources are received from western hands, and he reads the fathers and the acts of the ecumenical councils in western, often not very accurate editions. He learns the methods and techniques for dealing with collected materials in western schools. The history of the Orthodox is primarily

\footnotetext{
Ibidem, pp. 290-291, 294.

6 Ibidem, p. 299.

7 Ibidem, p. 300.
} 
known through the labours of many generations of western investigators and scholars. (...) The Orthodox theologian must also offer his own testimony to this world. ${ }^{8}$

What did Florovsky mean as he wrote about the need for the restoration of "philosophy of heart"? What the thinker called for was not so much "irrationalisation" of the pursuit of philosophy and theology, as revival of the Patristic style consisting in harmonious combination of intellectual reflection with intense perception of God in existential religious experience.

A theological system cannot be solely the fruit of a learning born in philosophical reflection. The experience of prayer, spiritual concentration, and pastoral care are also needed. (...) The theologian must speak to living people, to the living hearts (...). Learning in general is not and must not be a dia-lectical, but rather a dia-logical moment. ${ }^{9}$

The unilateral, solely speculative formation of the Russian philosophico-theological thought of the Silver Age, which omits the ascetic and mystic aspect, results - according to Florovsky's diagnosis in it being deprived of the prospect of its further fruitful development. It is on this account that the author of Ways of Russian Theology proposed turning towards the legacy of the Church Fathers, which had been forgotten and neglected in Russia, and creating a Neopatristic synthesis.

\section{Critical remarks}

At this point it is worth considering the following issue: to what extent was Florovsky right in assessing the condition of Russian thought as "straying," and in pointing to the Patristic tradition as the remedy for the existing situation? While answering the questions posed, it is appropriate to make four remarks.

8 Ibidem, pp. 303-304.

9 Ibidem, pp. 306-307. 
First, Florovsky - as Paul Gavrilyuk astutely observes - was not just a critic, but also a student of the religious-philosophical renaissance, and his "theological project was in fact deeply influenced by the problems and central themes of the renaissance both in its pre-revolutionary and post-revolutionary émigré expressions." ${ }^{10}$ Indeed, the author in question did not appear to be an outsider in relation to the Russian style of philosophising of which he was critical, but he spoke "from within" the renaissance, being its active participant, and even - to some extent - a cocreator of the émigré movement of the religious-philosophical revival. As he himself wrote: "the Russian philosophical «diaspora» marks a new moment, a new stage in the continuing historical fortunes of Russian thought." 11

As he criticised the old pathways of development of the Russian thought, postulating search for new ones (and then proposing a specified direction in the form of neo-patristics), Florovsky did not so much reject the existing achievements of his predecessors and contemporary authors, as he desired to reinforce their Christian foundation "constructed" - so to speak - out of the stones found in the field of the Eastern Christian tradition of the Church Fathers. Noteworthily, Vladimir Solovyov and, to an even greater degree, Fr. Pavel Florensky and Fr. Sergius Bulgakov readily included in their oeuvre references to the Patristic heritage, even if they did not make full use of it, and they allowed themselves to interpret some threads found in the Church Fathers in a loose and strictly philosophical manner (the concept of Sophia - Divine Wisdom ${ }^{12}$

10 P.L. Gavrilyuk, A New Chapter in the History of Russian Émigré Religious Philosophy: Georges Florovsky's unpublished manuscript, Russkaia filosofiia v emigratsii, "Analogia: The Pemptousia Journal for Theological Studies" 8 (2020), pp. 69-70.

11 Г.В. Флоровский, Русская философия в эмиграции, [in:] Историко-философский ежегодник 2013, ред. А.В. Черняев, Москва 2014, р. 314.

12 Florovsky distinguished two concepts of sophiology - the "ecclesiastical" one, dating back to the times of the Eastern Christian Fathers, and the gnostic one present in the thought of Solovyov and his followers. See G. Florovsky's letter to Fr. S. Bulgakov of 22.07.1926 (“Я не знаю, насколько тверды и самоотверженны миряне парижские...”: пятнадиать писем друг другу. Письма. Г.В. Флоровский - o. С. Булгакову (1925-1943)), [in:] Софиология и неопатристический синтез. Богословские итоги философского развития, ред. К.М. Антонов, Н.А. Ваганова, Москва 2013, р. 144. 
serving here as an example). Florovsky himself acknowledged that the "new religious-philosophical movement," which had been originated by Solovyov, was heading - through German idealism and the "great German mysticism" - towards Platonism, and then to the world of Patristics. ${ }^{13}$ It is also noteworthy that theistic existential philosophy, which emerged in the 2oth century and was pursued in the milieus of both Western philosophers (G. Marcel, P. Tillich) and Russian thinkers (N. Berdyaev), and which was criticised by Florovsky, was in many points close to existentially- and personalistically-oriented thought of Gregory Palamas and other Church Fathers. ${ }^{14}$

In Florovsky's opinion the main problem was that the existing "philosophy led to theology and did not follow from theology," ${ }^{15}$ while he postulated the opposite direction proceeding from Patristic theology and towards Christian philosophy - the so-called Christian Hellenism. It was in this spirit that Florovsky evaluated the representatives of the religiousphilosophical renaissance, beginning with Solovyov. On the one hand, he approved of their efforts aimed at reconciling fides and ratio (which was of no small importance in the era when positivism and various forms of materialism prevailed), but on the other hand he considered that the previous attempts had failed, because "rational justification of the truths of faith" (as it was conceived of by Solovyov) ${ }^{16}$ unduly focused on the rational element, leaving aside the life of faith. In other words, the emphasis was laid (in theological inquiries too) on philosophy, and not on theology viewed - in the spirit of the Church Fathers - as "theory," that is seeing and experiencing God. Lex orandi should go hand in hand with lex credendi, or even it should precede it.

In the essay Russian Philosophy in Emigration Florovsky states that Russian thought finds itself in statu nascendi, in the midst of quest and

13 See Г.В. Флоровский, Русская философия в эмиграции, op. cit., p. 325.

14 See В.П. Визгин, Экзистенциализм и богословская мысль Георгия Флоровского, “Философский журнал” 2 (2014), pp. 32-36.

15 Cf. Г.В. Флоровский, Русская философия в эмиграции, op. cit., p. 325.

16 See V. Solovyov, Selected Letters to Ekaterina Romanova, In V. Solovyov, Sophia, God and A Short Tale about the Antichrist, trans. by B. Jakim. Kettering 2014, pp. 93-94. 
fight, and remarks that "this characterisation is by no means insulting, nor is it supposed to testify to the chaotic or unformed nature of the Russian spirit." ${ }^{17}$ There are grounds for "a philosophical turning point, a new outburst of creativity", and this "premonition of synthesis is a source of inspiration for the Russian investigations." ${ }^{18}$ In Ways of Russian Theology, which was written several years later, the author was much more determined, stressing that the time to create the long-awaited synthesis had already come, and that it was supposed to be about a radical change in the paradigm and a bold turn towards the Church Fathers' theological inquiries, which were to shape the philosophical inquiries. It is theology that should inspire philosophical reflection, and not - which was the case before - just use the "services" provided by philosophical tools.

Summing up the previous observations, it must be stated that in his diagnosis of the religious-philosophical renaissance Florovsky adopted an ambivalent stance. As one reads passages from his writings (especially ones contained in Ways of Russian Theology), one may get the impression that he was an extremely harsh judge of the intellectual movement at the time. But a more thorough analysis of his entire oeuvre waters this opinion down a bit. Florovsky appreciated the very idea of philosophical and theological inquiries undertaken by Solovyov and his followers, and his "stinging" remarks serve as clear evidence that he was not indifferent about the fate of Russian thought. Of course, his assessment of the representatives of the religious-philosophical renaissance was sometimes quite uncompromising and even unfair - also in the light of his own analyses contained elsewhere - but his intention was certainly not so much to completely demolish the edifice of Russian philosophical thought, as to correct the existing projects, namely to reinforce their Patristic foundations. He proclaimed that "turning towards Patristics" did not mean "going backwards" towards the Church Fathers so much as "moving forwards" with the Fathers. ${ }^{19}$

17 Г.В. Флоровский, Русская философия в эмиграции, op. cit., p. 336.

18 Cf. Ibidem, p. 337.

19 See G. Florovsky, Ways of Russian Theology, vol. 2, p. 294. 
Łukasz Leonkiewicz characterises Florovsky's endeavour more decidedly. In his opinion "Russian religious thought was to Neopatristic theology like Neoplatonism was to Byzantine theology." ${ }^{20}$ If one takes into account the fact that various forms of Platonism were in the Byzantine Church denounced as heretical, then the polarisation between the positions of the religious-philosophical renaissance and Neopatristics gets even stronger. Let us restate that: of course, Florovsky spared no effort in criticising the former of the above-mentioned directions, but one can also point to numerous forms of interpenetration of both Neoplatonism and Byzantine theology, as well as Russian religious thought and Neopatristics. After all, Florovsky himself underwent philosophical formation with prominent Silver Age thinkers, and in his subsequent works he promoted the thesis about "Christian Hellenism" as a certain adaptation of Greek philosophical categories to the needs of Christian theology, which exactly happened in the Patristic Period. It is also worth recalling that Platonism was not always synonymous with heresy. The official denunciation of Platonism in the Eastern Church dates back to the 6th century and lasted until the decline of the Byzantine Empire, but earlier on it was none other than Plato who was depicted as "a Christian before Christ." Anyway, even in Byzantine thinkers such as St. Maxim the Confessor we can find many Platonic motifs. Mutatis mutandis, Russian thought too (as it refers to the Platonic line) does not have to be regarded as heretical in its entirety, or opposed to the Orthodox (Neo-)Patristic line.

Of course, the religious-philosophical renaissance and the Neopatristic synthesis can be treated as mutually opposing projects (which Florovsky did explicite), but it is impossible not to discern many links between them - after all, the Church Fathers, to whom the author of Ways of Russian Theology referred, on the one hand distinctly pointed to the special character of Christian theology, but on the other hand they did not

20 Ł. Leonkiewicz, Czy neopatrystyka była rosyjskim renesansem patrystycznym, http://www. ccpress.pl/recenzje/_Filozofia_rosyjskiego_renesansu_patrystycznego___rec._ks._dr._Lukasza_ Leonkiewicza_81 (accessed 01.04.2015). 
shy away ${ }^{21}$ from employing various philosophical categories, or touching upon subjects originated in the Greek philosophical tradition. ${ }^{22}$ Perhaps the representatives of the Neopatristic movement could, while following in their footsteps, include in their deliberation some threads developed by Russian philosophers (who, in turn, were in large measure inspired by Greek thinkers, in the spirit of "Christian Hellenism," propagated by Florovsky)? There is no doubt that answers to the same questions can vary and in fact (like in the case of the evaluation of sophiology) did vary (which after all is an ordinary phenomenon also with regard to "pure" philosophy free from theological motifs), but that is not a sufficient reason for placing theology and philosophy at opposite poles. Florovsky himself emphasised that even Tertullian, who was frequently portrayed as exemplifying the struggle between theology and philosophy (in line with the adage: "what indeed has Athens to do with Jerusalem?"), "could not avoid "inquisition" and "disputation," and did not hesitate to use the wisdom of the Greeks in the defence of the Christian faith."

The second remark about Florovsky's critique of the religiousphilosophical renaissance is concerned with his complaint about the Patristic heritage, which was proper to Orthodoxy, being neglected in Russian thought. After all Fr. Pavel Florensky, Florovsky's senior fellow and to some extent his spiritual director, with whom he corresponded in middle school years, called for revival of the style of pursuing philosophy and theology that was common in the times of the Church Fathers. As Fr. Wojciech Surówka quite rightly remarks in his review,

Florovsky's critical statement whereby "there is no and there was no Russian theology" is unfair to the immense wealth of achievements of his predecessors. (...) As late as the 19th century there were in Russia several centres that studied the Church Fathers' thought. Of course, this does not entirely pertain to what Florovsky

21 Even the "last" Byzantine Father who was considered to be the "mainstay" of the Orthodox, i.e. St. Gregory Palamas.

${ }^{22}$ See T. Obolevitch, Wiedza a wiara w myśli patrystycznej, Kraków 2015 (e-book).

23 G. Florovsky, Faith and Culture, in G. Florovsky, Collected Works, vol. 2, Belmont 1974, p. 23. 
had in mind, but to say that the "return to the Fathers" begins with Florovsky would be unfair to the immensity of work done at theological academies in Russia in the 19th century. ${ }^{24}$

Surówka indicates that the beginning of the "Patristic renaissance" can be dated as early as the 18th century, when Paisius Velichkovsky translated into Russian Philokalia, an anthology of Eastern Christian spirituality texts. The translation activity pursued at theological academies in the 19th century was the reason why, according to Boris Bobrinskoy, towards the end of the 19th century Russia had the most magnificent Patristic library (of Russian-language writings) in Europe. ${ }^{25}$ Hence - adds Surówka - "compared to works by V. Bolotov, V. Nesmelov, M. Posnov, Florovsky's books on the Church Fathers seem just modest."26 Indeed, saying that prior to Florovsky there was no research into Patristic thought is just wrong. What is more, he himself "stands on the shoulders of the Russian pre-revolutionary patristic scholars." ${ }^{27}$ In this sense, the author in question had no grounds to assess the condition of Russian theology as entirely formed under the influence of the Western and not Eastern-Byzantine tradition. ${ }^{28}$

It must, however, be noted that when Florovsky writes about the Patristic line in Russia having been severed, he does not mean a lack of translations or research papers on the Church Fathers so much as a different style of theology and philosophy in the Silver Age, to wit excessive rationalism, disregarding the mystical aspect, in other words pursuing theology a parte homini, and not a parte Dei, which is contrary to the definition. Philosophy too - in Florovsky's opinion - should not

24 W. Surówka, Podwójny Renesans (T. Obolevitch, Filozofia rosyjskiego renesansu patrystycznego, Copernicus Center Press, Kraków 2014), "Logos i Ethos" 1 (2015), p. 178.

25 See B. Bobrinskoy, Le Renouveau actuel de la patristique dans l'Orthodoxie, in Les Pères de l'Église au XXe siècle. Histoire - littérature - théologie, ed. coll., Paris 1997, pp. 437-444.

26 W. Surówka, Podwójny Renesans, op. cit., p. 180.

27 P.L. Gavrilyuk, Florovsky's Neopatristic Synthesis and the Future Ways of Orthodox Theology, [in:] Orthodox Constructions of the West, ed. G.E. Demacopoulos, A. Papanikolaou, Bronx-New York 2013, p. 120.

28 See also P.L. Gavrilyuk, Georges Florovsky and the Russian Religious Renaissance, op. cit., p. 3. 
be treated as an autonomous discipline, a product of "pure reason," but as synonymous with theology. And not the world, but the Word - as Florovsky pointed out in a private conversation with Rudolf Bultmann - should be the starting point for theology. ${ }^{29}$ That is precisely why the thinker was critical of writings by such renowned Russian theologians as Viktor Nesmelov and Mikhail Tareev (to say nothing of the Silver Age philosophers and their most prominent representative, Solovyov). What he meant was not so much a failure to mention Patristic threads in their writings, as the distortion ('pseudomorphosis' in Florovsky-speak) of the Patristic style, the starting point of which was the Revelation and personal religious observances. By way of illustration, he wrote that Solovyov "attempted to construct an ecclesiastical synthesis from nonecclesiastical experience,"30 and that he himself saw his departure from Solovyov as "his personal religious obligation and another task facing the contemporary religious-philosophical thought." ${ }^{31}$

As he criticised German idealism, Russian religious-philosophical renaissance, Catholic neo-Thomism as well as other philosophical movements as excessively rationalistic, Florovsky appeared not to notice other features common to these trends and the great syntheses of the Patristic Period. Philosophy (and especially the history of philosophy) is all too often given to this temptation to yield to clichés, superficial classifications of some or other authors as "idealists" or "materialists," "Platonists" or "Artistotelians." An insightful analysis of some passages by individual thinkers not infrequently shows that their views are much more nuanced. It is indisputable that in his judgements Florovsky was many a time overly formulaic, which to some degree is understandable, if we take into account the fact that he was actuated by the goal to "reverse" the existing line of Russian (and not only) thought development, and to set it on the Neopatristic track. That is where, inter alia, lies the

\footnotetext{
29 See A. Blane, A Sketch of the Life of Georges Florovsky, [in:] Georges Florovsky, Russian Intellectual and Orthodox Churchman, ed. A. Blane, Crestwood 1993, p. 139.

30 G. Florovsky, Ways of Russian Theology, vol. 2, p. 85.

31 G. Florovsky's letter to Fr. S. Bulgakov of 30.12.1925 (“Я не знаю, насколько тверды u самоотверженны миряне парижские..., ор. cit.), p. 131.
} 
fundamental contradiction, or at least incoherence of Florovsky's project: on the one hand, he declared sensitivity to new ideas and topical problems, readiness to engage in dialogue with a variety of philosophical ideas (as long as that was done ad mentem patris), but on the other hand he was not always tolerant even of the tradition that he himself grew out of as a thinker, thereby evincing a tendency to ignore and underestimate many leading philosophical trends at the time. ${ }^{32}$

This is connected with another, third remark concerned with the critique of the radical Neopatristic project by Florovsky. Namely, as we ponder the question of which of the programmes developed by Russian thinkers - the religious-philosophical renaissance or the Neopatristic synthesis - can play a positive role in the contemporary postmodernist and post-secular society, it must be noted that both the trends have great potential, and because of this they need to be treated as complementary strategies. ${ }^{33}$ In particular, the "Russian school" (to use the term coined by Fr. Alexander Schmemann), ${ }^{34}$ which was criticised by Florovsky, developed a lot of interesting and promising ideas (including the concept of Sophia) concerned with natural philosophy and the relationship between science and religion. Besides, the religiousphilosophical renaissance thinkers (especially Berdyaev) emphasised the significance of human freedom to an immeasurably greater degree than the representatives of Neopatristics did. ${ }^{35}$

Fourth, it must be borne in mind that as Florovsky postulated the revival of Patristic thought and development of a Neopatristic synthesis, he himself was not a systematic thinker, neither as a historian (and critic)

32 See A.В. Черняев, Г.В. Флоровский как философ и историк русской мысли, Москва 2010, pp. 93-94.

${ }^{33}$ See N. Asproulis, Is Dialogue between Orthodox Theology and Post-modernity Possible? The Case of the Russian and Neo-patristic Schools, "Communio viatorum" 54 (2012) no. 2, p. 221.

${ }^{34}$ See K. Stöckl, Modernity and its Critique in $20^{\text {th }}$ Century, "Studies in East European Thought" 58 (2006) no. 4, p. 251.

35 See N. Asproulis, Is Dialogue between Orthodox Theology and Post-modernity Possible?, op. cit., p. 213. 
of Russian thought, ${ }^{36}$ nor as the originator of the Neopatristic project. He did not propound a coherent concept of "Christian Hellenism," but only listed characteristics required of philosophy pursued within Patristic theology, inter alia sobornost' (conciliarity), Christian Hellenism and historicism. "Florovsky rarely, if at all, speaks of the operation of a synthesis with sufficient methodological precision." ${ }^{38}$ What is more, regardless of (or perhaps owing to) their polemical character, his works devoted to Russian thought (particularly Ways of Russian Theology), played a crucial role in the development and reception of the Silver Age philosophy, while Florovsky's opus vitae, i.e. Neopatristics, languished in the designing stage. ${ }^{39}$ For all his desperate attempts at going beyond the tradition of the Silver Age, he forever lingered within the orbit of its influence.

\section{The status of philosophy: G. Florovsky and V. Zenkovsky}

As one considers the status of the Russian religious-philosophical renaissance and the Neopatristic synthesis, it is worth briefly juxtaposing Florovsky's approach with a position represented by another émigré thinker, Vasily Zenkovsky (1881-1962). The latter one, like Florovsky, was for some time a member of the Brotherhood of Sophia, which was established in 1923 in Prerov, contributed to periodical "Путь," as well as lectured in philosophy, psychology, apologetics and history of

36 Cf. А.В. Черняев, Г.В. Флоровский как философ и историк русской мысли, op. cit., pp. 62-64.

37 See G. Florovsky, Ways of Russian Theology, vol. 2, p. 297.

38 P.L. Gavrilyuk, Georges Florovsky's Reading of Maximus: Anti-Bulgakov or Pro-Bulgakov?, [in:] Knowing the Purpose of Creation through the Resurrection: Proceedings of Symposium on St. Maximus the Confessor, ed. M. Vasiljević, Alhambra 2013, p. 409. Cf. idem, Florovsky's Neopatristic Synthesis and the Future Ways of Orthodox Theology, op. cit., p. 102.

39 The Neopatristic synthesis was constructed by other theologians, e.g. Vladimir Lossky, John Meyendorff, Paul Evdokimov, and currently - Sergey Khoruzhy in Russia, Joanis Zizioulas in Greece, and Alexei Nesteruk in Russia and England. See T. Obolevitch, Filozofia rosyjskiego renesansu patrystycznego, op. cit., pp. 276-287; П. Гаврилюк, Влияние протоиерея Георгия Флоровского на православное богословие ХХ века, “Труди Київскої духовної академії” 20 (2014), pp. 71-93. 
religion at Saint Serge Institute in Paris (after Fr. S. Bulgakov death he acted as the school dean). Zenkovsky was also a member of an informal Patristics club run by Florovsky in Prague. ${ }^{40}$ Both the authors shared an interest in the history of Russian philosophy. They were involved in the theological commission investigating Bulgakov's sophiology (1935), but Zenkovsky adopted a more moderate stance: "while not concealing the points of divergence with Fr. S. Bulgakov on a given issue, he supported the commission's general conclusion whereby there were no grounds for such harsh accusations against the latter." ${ }^{\prime 1}$ Several years earlier, in 1930, Zenkovsky wrote a paper entitled Overcoming Platonism and the Problem of Sophianity of the World, in which - like Florovsky in his earlier works Creation and Creaturehood (1927) and The Idea of Creation in Christian Philosophy (1928) - he brought up the subject of the relationship between God and the world, defending the belief that only the Christian concept of the creation of the world makes it possible to circumvent the pitfall of pantheism. ${ }^{42}$ At the same time Zenkovsky defended Fr. Bulgakov against the accusations of the ignorance of the Patristic heritage, explaining that it was precisely from him that he had borrowed a number of works by the Fathers. ${ }^{43}$

Of particular note is Zenkovsky's book, a classic now, entitled A History of Russian Philosophy (vol. 1 - 1948, vol. 2 - 1950) regarded as the first comprehensive study of the subject. While in his Ways of

40 See П. Гаврилюк, Влияние протоиерея Георгия Флоровского на на православное богословие XX века, op. cit., p. 73. For the first time Zenkovsky encountered the Church Fathers' writings in his student years, in 1902, as he was preparing for the compulsory exam in theology. Sее прот. В. Зеньковский, Очерк внутренней моей биографии, “Вестник РСХД” 66-67 (1962), p. 11.

41 В. Летцев, “Прежде всего, он искал подлинности...” Очерк жизненного и творческого пути В.В. Зеньковского, Киев 2014, р. 132.

42 There is not enough room here to discuss the differences between Florovsky and Zenkovsky, so let us only remark that while the latter interpreted the relationship between God and the world in terms of the uncreated Sophia and the created Sophia (just like S. Bulgakov), Florovsky, who sometimes employed the concept of Sophia, was far from identifying it with the Patristic concept of the Divine energy.

43 Seе В. Зеньковский, Мое участие в церковной жизни, “Вестник РСХД” 196 (2010), p. 238 . 
Russian Theology Florovsky chiefly pointed to various shortcomings of Russian thought, mentioning above all numerous borrowings from the West, lack of originality and derivativeness, as well as postulating search for new development pathways, Zenkovsky presented one of the best syntheses of all Russian philosophy, including the religiousphilosophical renaissance of that time. In his History he attempted to objectively expound Russian philosophy, trying to steer clear of both ironic remarks, which was characteristic of Florovsky, and exaggerated defence of the alleged specificity of Russian thought. ${ }^{44}$ For this work he was awarded a well-deserved degree of doctor of philosophy. In the book he critiqued Solovyov's concept of al-unity, ${ }^{45}$ which was developed by many other thinkers of the Russian renaissance as well, but on the whole he held in high regard the very idea of synthesis of philosophical, scientific and religious thought. ${ }^{46}$ For Florovsky such a strategy was unacceptable: he did not call for reconciliation between philosophy and theology, but postulated replacement of philosophy with theology, or rather overcoming the former by the latter. Zenkovsky "resolutely rejected the rift between faith and knowledge, ${ }^{37}$ and on this account he developed the concept of Christian philosophy. ${ }^{48}$ Interestingly enough,

44 Cf. O.T. Ermishin, On Two Conceptions of Russian Philosophy. V.V.Zenkovsky, B.V. Iakovenko, G.G. Shpet, trans. L.E. Wolfson, "Russian Studies in Philosophy" 43 (2004-2005) no. 3, p. 83.

${ }_{45}$ See also his paper Vladimir Solovyov's Idea of All-Unity (1955): В.В. Зеньковский, Идея всеединства в философии Владимира Соловьева, [in:] idem, Собрание сочинений, т. 1: О русской философии $и$ литературе. Статьи, очерки $и$ рецензии 1912-1961, Москва 2008, pp. 228-245.

46 See ibidem, pp. 229, 245; V.V. Zenkovsky, A History of Russian Philosophy, vol. 2, trans. by G.L. Kline, New York 1953, pp. 482, 492-493.

47 В.В. Зеньковский, Основы христианской философии, т. 1, Москва 1997, p. 21.

48 In the book The Fundamentals of Christian Philosophy. The first volume, devoted to gnoseology, was published in 1961, and the second volume, on cosmology - only after the author's death, in 1964; the third volume was supposed to treat of Christian anthropology, but Zenkovsky did not manage to write it. See also J. Voskressenskaia, The Unity of Reason and Faith as a Human Challenge. The Problem of Christian Culture and Philosophy in E. Trubetskoy and V. Zenkovsky, [in:] Faith and Reason in Russian Thought, ed. T. Obolevitch, P. Rojek, Kraków 2015, pp. 225-229; O. Ermishin, The Problem of Christian Culture in the Philosophy of Vasily Zenkovsky, [in:] Apology of Culture. Religion and Culture in Russian Thought, ed. A. Mrówczyński-Van Allen, T. Obolevitch, P. Rojek, Eugene 2015, pp. 72-78. 
in this respect he invoked the stance adopted by the Church Fathers, who - as he stressed - taught about "the necessity to restore the lost unity of human spirit," and he considered "all philosophical constructs in the light of Christianity." ${ }^{49}$ Florovsky (beginning with the essay entitled Philosophy and religion, 1923) treated theology as the only legitimate sphere of cognition of the Divine reality and of its relationship with the world. He wrote: "Religion and philosophy, faith and knowledge are diverse by nature, and autonomous in regard to each other," ${ }^{50}$ thereby rejecting any attempts at constructing independent Christian philosophy. In his opinion Christian philosophy (i.e. "Christian Hellenism") has a reason for being only as a consequence or element of theology.

Both Florovsky and Zenkovsky denied the possibility of rationalising the truths of faith, and by extension rejected the programme that Solovyov and the other representatives of the religious-philosophical renaissance were motivated to implement. According to Florovsky: "The «rational» justification of faith is tantamount to its destruction: faith justifies itself," ${ }^{51}$ while Zenkovsky argued thus: "it is not faith that needs to be justified in the face of reason, but the other way round, reason itself needs illumination and enlightenment through superior powers." ${ }^{2}$ For this reason, like Florovsky, he writes that in Solovyov's system one can discern echoes of secularism and modernist pantheism, which makes it impossible to call it "Christian philosophy." ${ }^{53}$ In Solovyov's thought "Christian doctrine is not enriched at the expense of philosophy; on the contrary, he introduces Christian ideas into philosophy in order to enrich and fructify philosophic thought." ${ }^{24}$ Clearly, this evaluation comes very close to Florovsky's diagnosis.

\footnotetext{
49 В.В. Зеньковский, Очерк моей философской системы, „Вестник РСХД” 66-67 (1962),

50 С. Г.В. Флоровский, Философия и религия, „Философские науки” 10 (2013), p. 103.

51 Ibidem.

52 В.В. Зеньковский, Идея всеединства в философии Владимира Соловьева, ор. cit., p. 229.

53 See V.V. Zenkovsky, A History of Russian Philosophy, vol. 2, pp. 492, 529; В.В. Зеньковский, Очерк моей философской системы, op. cit., p. 38.

54 Cf. V.V. Zenkovsky, A History of Russian Philosophy, vol. 2, p. 529.
} p. 37. 
Therefore, Florovsky and Zenkovsky - the authors who laid the foundations for research into Russian thought - agreed on the general direction of its development: it was supposed to be connected with the search for the Eastern Christian roots and with the overcoming of the rationalist approach specific to Western thought (and many Russian philosophers of the Silver Age). In the spirit of Florovsky, Zenkovsky claimed that the contemporary times were characterised by the desire for a religious revival and "the renewal of the mind," which the 19th-century Slavophiles wrote about. ${ }^{55}$ At the same time the authors under analysis differed in their understanding of the longed-for revival: while Zenkovsky believed that philosophy needed further advancement, though all its manifestations of secularism and rationalism (or "modernism" to put it more generally) were to be cleared, Florovsky suggested turning towards theology pursued in the spirit of the Church Fathers, and - only in its bosom - developing "Christian Hellenism," which - and this is evidenced by the thinker's extant theological testament - he understood literally, that is as a turn towards the thought of the Greek Church Fathers, excluding the attempt at entering into dialogue with any contemporary philosophers (including Russian ones). ${ }^{56}$

\section{Conclusion}

The Russian religious-philosophical renaissance is a thing of the past, ${ }^{57}$ whereas various attempts at developing a Neopatristic synthesis (or syntheses) have continued till this day. ${ }^{58}$ Does that mean that

55 В.В. Зеньковский, Наша эпоха, [in:] idem, Собрание сочинений, т. 2: О православии и религиозной культуре. Статьи и очерки 1916-1957, Москва 2008, p. 406.

56 See P. Gavrilyuk, Florovsky's Neopatristic Synthesis and the Future Ways of Orthodox Theology, op. cit., p. 116.

57 It is believed that the cut-off date is the year 1950, or at the latest 1954 - the year in which Ivan Ilyin and Boris Vysheslavtsev, its last representatives, died. See S. Mazurek, Rosyjski renesans religijno-filozoficzny. Próba syntezy, Warszawa 2008, p. 222.

58 Some, however, are of the opinion that the very word "neopatristics" is an oxymoron, and that we should rather speak about "post-patristics." See Э. Лаут, Пост-патристическое богословие, или за пределами неопатристического синтеза, http://www.bogoslov.ru/text/1982765.html. 
Florovsky was a far-sighted author or even a prophet who ushered in a new era in thought development? Indeed, he was right in pointing to the urgent need to revive the thought of the Church Fathers (and he was not alone in that sentiment, ${ }^{59}$ which has already been emphasised), although he did not appreciate the possibilities - also for the postulated Patristic revival - offered by the Russian philosophy of the Silver Age. It is also worth acknowledging the fact that the "demise" of the religiousphilosophical renaissance was brought about by a number of factors which it is impossible to thoroughly analyse here. ${ }^{60}$ Anyway, today's Russian philosophy is at an impasse: admittedly, there are a good many prominent researcher-historians, but there are not enough independent, original creators. The most interesting and promising attempts are in fact made by representatives of the Neopatristic movement (of particular note are such authors as the above-mentioned Greek Joanis Zizioulas, and Christos Jannaras, who are regarded as the most distinguished contemporary Orthodox thinkers).

Did philosophy pursued within Eastern Christianity really have to return to theology, which is what Florovsky wished, or perhaps it does not fully exploit its potential (and especially its intrinsic religious element or Christian leaven) in this day and age? Let us leave this question unanswered, inviting the Reader to join in the discussion.

59 Before Florovsky the one who worked on the revival of the forgotten Patristic heritage was Fr. Vasily Krivoshein (nota bene, he was critical of Florovsky's postulate). It bears recalling a similar tendency prevalent in the 1930s-50s among Catholic and Protestant theologians.

60 Even though some of the reasons for the demise of the Russian religious-philosophical renaissance are mentioned by Stanisław Mazurek (S. Mazurek, Rosyjski renesans religijno-filozoficzny, op. cit., pp. 230-232), the problem still awaits exploration. 


\section{Abstract \\ George Florovsky's Critique of the Russian Religious- Philosophical Renaissance: an Attempt at Evaluation}

In the present paper I present a project of Neopatristic synthesis by prominent Russian thinker Fr. George Florovsky, as well as the main reasons for which he criticised the existing style and direction of development of Russian thought in the form of religiousphilosophical renaissance, or "the Silver Age." By engaging in polemics with Florovsky's approach, I advance four remarks. First, Florovsky himself was under the influence of the Russian religious-philosophical renaissance. Second, it was not Florovsky who initiated the Patristic studies in Russia, since they had been conducted from the $18^{\text {th }}$ century. Third, the Neopatristic synthesis and the "Silver Age" philosophy could have been perceived as complementary projects rather than contrary in their tenor. Fourth, Florovsky left his own postulate uncompleted. In the concluding part of the paper I compare Florovsky's and Zenkovsky's approaches, arguing in favour of the latter thinker.

\section{Keywords}

George Florovsky, Russian Religious Philosophy, Neopatristics

\section{Bibliography}

Asproulis N., Is Dialogue between Orthodox Theology and Post-modernity Possible? The

Case of the Russian and Neo-patristic Schools, "Communio viatorum" 54 (2012) no.

2, pp. 203-222.

Blane A., A Sketch of the Life of Georges Florovsky, [in:] Georges Florovsky, Russian

Intellectual and Orthodox Churchman, ed. A. Blane, Crestwood 1993, pp. 11-217.

Bobrinskoy B., Le Renouveau actuel de la patristique dans l'Orthodoxie, in Les Pères de

l'Église au XXe siècle. Histoire - littérature - théologie, ed. coll., Paris 1997, pp. 437-444. Chernjaev A.V., G.V. Florovskij kak filosof i istorik russkoj mysli, Moskva 2010.

Chetverikov S., Starec Paisij Velichkovskij, Minsk 2006. 
Ermishin O., The Problem of Christian Culture in the Philosophy of Vasily Zenkovsky, [in:] Apology of Culture. Religion and Culture in Russian Thought, ed. A. Mrówczyński-Van Allen, T. Obolevitch, P. Rojek, Eugene 2015, pp. 72-78.

Ermishin O.T., On Two Conceptions of Russian Philosophy. V.V. Zenkovsky, B.V. Iakovenko, G.G. Shpet, trans. L.E. Wolfson, "Russian Studies in Philosophy" 43 (2004-2005) no. 3, pp. 81-89.

Florovsky G., Faith and Culture, in G. Florovsky, Collected Works, Vol. 2, Belmont 1974, pp. 9-30.

Florovsky G., Ways of Russian Theology, Vol. 2, trans. by R. L. Nichols, Vaduz 1987.

Florovskij G.V., Filosofija i religija, "Filosofskie nauki" 10 (2013), pp. 101-105.

Florovskij G.V., Russkaja filosofija v jemigracii, [in:] Istoriko-filosofskij ezhegodnik 2013, red. A.V. Chernjaev, Moskva 2014, pp. 314-337.

Gavrilyuk P.L., Florovsky's Neopatristic Synthesis and the Future Ways of Orthodox Theology, [in:] Orthodox Constructions of the West, ed. G.E. Demacopoulos, A. Papanikolaou, Bronx-New York 2013, pp. 102-124.

Gavrilyuk P.L., Georges Florovsky and the Russian Religious Renaissance, Oxford 2013. Gavrilyuk P.L., Georges Florovsky's Reading of Maximus: Anti-Bulgakov or Pro-Bulgakov?, [in:] Knowing the Purpose of Creation through the Resurrection: Proceedings of Symposium on St. Maximus the Confessor, ed. M. Vasiljević, Alhambra 2013, pp. 407-415.

Gavriljuk P., Vlijanie protoiereja Georgija Florovskogo na pravoslavnoe bogoslovie HH veka, “Trudi Kiïvskoï duhovnoï akademiï” 20 (2014), pp. 71-93.

Gavrilyuk P.L., A New Chapter in the History of Russian Émigré Religious Philosophy: Georges Florovsky's unpublished manuscript, Russkaia filosofia v emigratsii, "Analogia: The Pemptousia Journal for Theological Studies" 8 (2020), pp. 69-75.

"Ja ne znaju, naskol'ko tverdy i samootverzhenny mirjane parizhskie...": pjatnadcat' pisem drug drugu. Pis'ma. G.V. Florovskij - o. S. Bulgakovu (1925-1943), [in:] Sofiologija i neopatristicheskij sintez. Bogoslovskie itogi filosofskogo razvitija, ed. K.M. Antonov, N.A. Vaganova, Moskva 2013, pp. 115-128. Laut Je., Postpatristicheskoe bogoslovie, ili za predelami neopatristicheskogo sinteza, http:// www.bogoslov.ru/text/1982765.html.

Leonkiewicz Ł., Czy neopatrystyka była rosyjskim renesansem patrystycznym, http://www. ccpress.pl/recenzje/_Filozofia_rosyjskiego_renesansu_patrystycznego__-_rec._ks._ dr._Lukasza_Leonkiewicza_81 (accessed 01.04.2015). 
Letcev V., "Prezhde vsego, on iskal podlinnosti..." Ocherk zhiznennogo i tvorcheskogo puti V.V. Zen'kovskogo, Kiev 2014.

Mazurek S., Rosyjski renesans religijno-filozoficzny. Próba syntezy, Warszawa 2008.

Obolevitch T., Filozofia rosyjskiego renesansu patrystycznego: o. Gieorgij Fłorowski, Włodzimierz Łosski i inni, Kraków 2014.

Obolevitch T., Wiedza a wiara w myśli patrystycznej, Kraków 2015 (e-book).

Sauvé R.J., Florovsky’s Tradition, “Greek Orthodox Theological Review” 55 (2010) no. 1-4, pp. 213-241.

Stöckl K., Modernity and its Critique in $20^{\text {th }}$ Century, "Studies in East European Thought" 58 (2006) no. 4, pp. 243-269.

Solovyov V., Selected Letters to Ekaterina Romanova, In V. Solovyov, Sophia, God and A Short Tale about the Antichrist, trans. by B. Jakim. Kettering 2014, pp. 71-100.

Surówka W., Podwójny Renesans (T. Obolevitch, Filozofia rosyjskiego renesansu patrystycznego, Copernicus Center Press, Kraków 2014), "Logos i Ethos" 1 (2015), pp. 167-181.

Vizgin V.P., Jekzistencializm i bogoslovskaja mysl' Georgija Florovskogo, "Filosofskij zhurnal" 2 (2014), pp. 24-37.

Voskressenskaia J., The Unity of Reason and Faith as a Human Challenge. The Problem of Christian Culture and Philosophy in E. Trubetskoy and V. Zenkovsky, [in:] Faith and Reason in Russian Thought, ed. T. Obolevitch, P. Rojek, Kraków 2015, pp. 225-229.

Zenkovsky V.V., A History of Russian Philosophy, vol. 2, trans. by G.L. Kline, New York 1953.

Zen'kovskij V., Moe uchastie v cerkovnoj zhizni, "Vestnik RSHD” 196 (2010), pp. 225-239.

Zen'kovskij V., Ocherk vnutrennej moej biografii, "Vestnik RSHD” 66-67 (1962), pp. 8-15.

Zen'kovskij V.V., Ideja vseedinstva v filosofii Vladimira Solov'eva, [in:] idem, Sobranie sochinenij, t. 1: O russkoj filosofii i literature. Stat'i, ocherki i recenzii 1912-1961, Moskva 2008, pp. 228-245.

Zen'kovskij V.V., Nasha jepoha, [in:] idem, Sobranie sochinenij, t. 2: O pravoslavii i religioznoj kul'ture. Stat'i i ocherki 1916-1957, Moskva 2008, pp. 402-449.

Zen'kovskij V.V., Osnovy hristianskoj filosofii, t. 1, Moskva 1997.

Zen’kovskij V.V., Ocherk moej filosofskoj sistemy, "Vestnik RSHD” 66-67 (1962), pp. 37-38. 